\title{
Nanostructured Films Produced from the Bleached Pinus sp. Kraft Pulp
}

\author{
Lívia Cássia Viana ${ }^{1}$ (D), Graciela Ines Bolzon de Muñiz ${ }^{2}$ (D), \\ Washington Luiz Esteves Magalhães ${ }^{3}$ (1), Alan Sulato de Andrade ${ }^{2}$ (1), \\ Silvana Nisgoski² (D), Daniele Cristina Potulski² (D) \\ ${ }^{1}$ Universidade Federal do Tocantins (UFT), Gurupi, TO, Brasil \\ ${ }^{2}$ Universidade Federal do Paraná (UFPR), Curitiba, PR, Brasil \\ ${ }^{3}$ Empresa Brasileira de Pesquisa Agropecuária (Embrapa), Colombo, PR, Brasil
}

\begin{abstract}
This study investigates the physical and mechanical properties of nanostructured films produced from Pinus sp. kraft pulp. To obtain the nanocellulose, the bleached kraft pulp was submitted to six different grinding regimes: two, five, ten, 20,30 , and 40 passes through the grinder. The influence of the number of passes was evaluated through the films' physical and mechanical properties. The results show that the nanofibers reduced the thickness and considerably increased the density values of the fabricated films. The tensile strength increased more than $300 \%$ and the burst index was ten times higher in relation to normal papers. The more compact structure and lower porosity caused by the larger contact surface between nanofibers in the nanostructured films resulted in higher values of density, tensile strength, and burst resistance.
\end{abstract}

Keywords: nanocellulose, grinder, mechanical properties, density, crystallinity index.

Filmes Nanoestruturados Produzidos a partir de Polpa Kraft Branqueada de Pinus sp.

\section{RESUMO}

Este trabalho investiga as propriedades físicas e mecânicas de filmes nanoestruturados produzidos a partir da polpa kraft branqueada de Pinus sp. Para obter a nanocelulose, a polpa kraft branqueada foi submetida a seis diferentes intensidades de desfibrilação pelo moinho: dois, cinco, dez, 20, 30 e 40 passes. A influência do número de passes foi avaliada por meio das propriedades físicas e mecânicas dos filmes. Os resultados indicam que a presença de nanofibrilas reduziu a espessura e aumentou consideravelmente os valores de densidade dos filmes fabricados. Observou-se aumento da resistência à tração de $300 \%$ e o índice de ruptura foi dez vezes maior em relação aos papéis normais. A estrutura mais compacta e a menor porosidade causada pela maior superfície de contato entre as nanofibrilas nos filmes resultaram em maiores valores de densidade, resistência à tração e resistência à ruptura.

Palavras-chave: nanocelulose, moinho, propriedades mecânicas, densidade, índice de cristalinidade. 


\section{INTRODUCTION AND OBJECTIVES}

The growing search for products that cause less impact on the environment has motivated the study and application of biodegradable and renewable raw materials. Among these natural resources, cellulose stands out as a renewable, biodegradable and inexpensive material, also presenting excellent physical and mechanical properties.

In nanotechnology, attainment and use of the cellulose's nanofibers and its applications in composite materials have attracted attention of researchers due to its high resistance and rigidity and low weight (Julkapli \& Bagheri, 2017). Besides those desirable mechanical properties, cellulose nanofibers present other interesting features for reinforcing nanocomposites, enabling optically transparent films with a very low thermal expansion coefficient that are still easily foldable (Fall et al., 2014; Kargarzadeh et al., 2017; Shimizu et al., 2016; Toivonen et al., 2015).

Wood has been the main source of cellulose used for the production of nanofibrils (Berglund \& Burgert, 2018; Chinga-Carrasco, 2011). Vegetable fibers, especially from wood, are important sources of reinforcement material for the substitution of conventional fibers in composites for semi-structured and structured applications. The high percentage of cellulose in wood, which in terms of mass is the most important component of the cell wall (occupying about $45 \%$ ), along with the fact that as a renewable material it has less impact on the environment, encourages research to produce nanofibers from this resource.

The wall of wood cells is composed of layers of microfibril aggregates combined with hemicellulose and lignin (Sjöström, 1993). The obtainment and separation of nanofibers from the cell wall requires some form of chemical and/or mechanical treatment. According to existing works, cellulose nanofibers can be obtained from the disintegration of cellulose submitted to a mechanical homogenization process in which it is degraded, exposing and opening the surfaces previously situated inside the fibers, fibrils and microfibrils (Brodin \& Gregersen, 2014; Suopajärvi et al., 2017; Turbak et al., 1983). This process causes a significant decrease in fibers' size and consequently an increase of specific areas, promoting better connection between the microfibrils (Jonoobi et al., 2012).
Cellulose nanofibers are hydrophilic, with high capacity to form strong interfibrillar hydrogen bonds that produce a material with high density and resistance properties. They can be used in nanocellulosic films for coating or as reinforcement for many products in the paper industry (Balea et al., 2018; Campano et al., 2018; He et al., 2016; Josset et al., 2014). Due to their larger specific surface area, nanofibers also have increased accessibility, solubility, and reactivity (Ioelovich \& Larina, 1999).

Recent research shows that in relation to conventional material, the paper or film produced from nanocellulose presents higher density, flexibility, and mechanical resistance, as well as lower porosity (Balea et al., 2016; Bharimalla et al., 2015; González et al., 2014). Cellulosic nanofiber films have properties considered satisfactory for application in packages, a fact that explains the food industry's increasing interest in replacing packaging made of petroleum-based polymers with biodegradable materials such as paper coated with cellulosic nanofilms (Aulin \& Ström, 2013; Herrera et al., 2016; Vandermoere et al., 2011).

The isolation of cellulosic nanofibers from wood sawdust and cellulosic pulp has been reported through the mechanical process of grinding or defibrillation, by using a grinder that allows obtaining nanofibers with average width around $15 \mathrm{~nm}$ and length measured in micrometers (Abe et al., 2007; Abe \& Yano, 2010; Ifuku et al., 2010; Panthapulakkal \& Sain, 2012; Vartiainen et al., 2011; Wang et al., 2013; Wang et al., 2015).

In this context, this article aims at investigating the physical and mechanical properties and characteristics of nanostructured films from bleached Pinus sp. kraft pulp, obtained through different numbers of passes through the defibrillator grinder.

\section{MATERIALS AND METHODS}

\subsection{Material}

An unbleached Pinus sp. kraft pulp obtained from pulp and paper industry was used. It went through a mechanical process of tracheids disintegration, after which it was washed to remove excess cooking liquor and then submitted to centrifugation and bleaching. 
The bleaching process was adapted from Wise et al. (1946). For each $10 \mathrm{~g}$ of dried pulp, $1.5 \mathrm{~g}$ of $80 \%$ sodium chlorite $\left(\mathrm{NaClO}_{2}\right)$ and 10 drops of glacial acetic acid in $160 \mathrm{~mL}$ of distilled water were added. The material was maintained in a water bath at $80{ }^{\circ} \mathrm{C}$ for one hour. Three bleaching steps were performed, and in each interval the pulp was abundantly washed to remove possible residues of $\mathrm{NaClO}_{2}$.

The kappa number (Tappi, 1999b) used to measure the quantity of residual lignin in the pulp was determined before and after the bleaching. The values found were 51.7 and 3.6, respectively.

\subsection{Obtainment of cellulose nanofibers}

The concentration of the bleached kraft pulp in suspension was adjusted to $1 \mathrm{wt} \%$ by adding water
(Iwamoto et al., 2008), followed by mechanical defibrillation in a Masuko Sangyo Super Masscolloider grinder (MKCA6-3; Masuko Sangyo Co., Ltd.) (Figure 1) at a frequency of $1,500 \mathrm{rpm}$. Six different numbers of passes through the grinder were evaluated: two, five, ten, 20,30 , and 40 , as well as treatment without any mechanical processing, thus totaling seven treatments. These treatments were called T02, T05, T10, T20, T30, $\mathrm{T} 40$, and T00, respectively.

After a few passes through the grinder, the cellulosic suspension is transformed into a stable suspension, acquiring a gel-like aspect, as observed by Besbes et al. (2011), called a nanocellulosic suspension. Part of the obtained nanocellulosic suspension was used to determine the viscosity of treatments and to observe nanofibers through transmission electron microscopy (TEM).

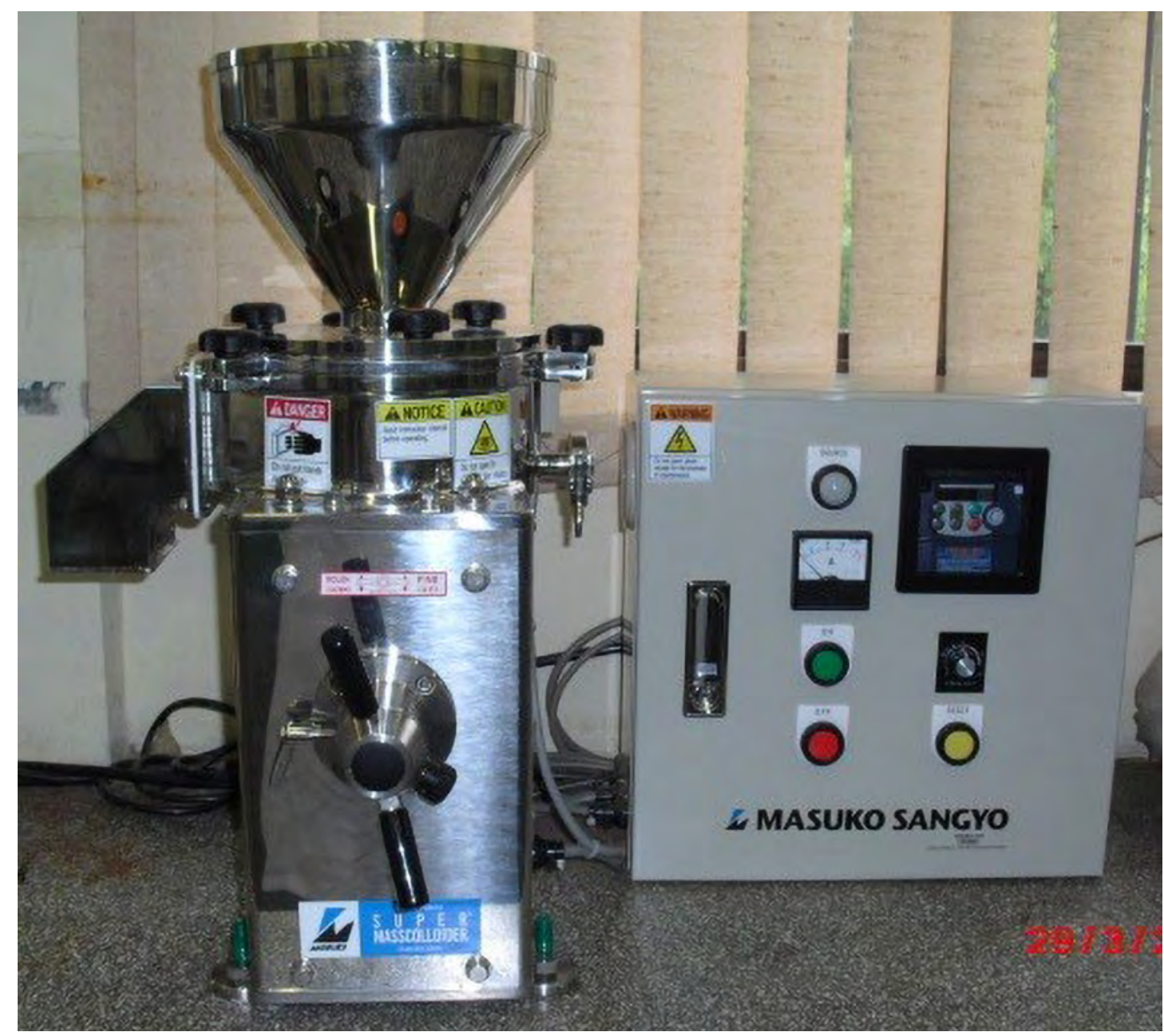

Figure 1. Masuko Sangyo Super Masscolloider grinder. 


\subsection{Preparation of nanostructured cellulosic films}

Nanostructured films were produced through deposition of the nanocellulosic suspension on a whole filter paper placed under a nylon screen (opening: $5 \mu \mathrm{m}$ ) and then filtered in a vacuum. After being filtered, the films were taken for pre-drying at $60^{\circ} \mathrm{C}$ in an oven for 10 minutes and then dried in the paper forming machine at a temperature of around $70^{\circ} \mathrm{C}$ and constant pressure of $80 \mathrm{KPa}$. The desirable grammage of $60 \mathrm{~g} . \mathrm{m}^{-2}$ was established.

The paper samples were made with a Rapid-Köethen apparatus, with drying temperature of $90 \pm 2{ }^{\circ} \mathrm{C}$ and pressure of $80 \mathrm{Kpa}$, according to the ISO 5269-2 (ISO, 1980) and Tappi T 205 sp-02 (Tappi, 2004a) standards. Each treatment was repeated five times, for a total of 30 nanostructured films and 5 papers.

The nanostructured films and papers were stored in an acclimatized room with temperature of $23 \pm 2{ }^{\circ} \mathrm{C}$ and relative humidity of $50 \pm 2 \%$ for further preparation of the sample and measurement of physical parameters (thickness, density, and absorption) and mechanical testing (tensile strength and burst resistance), as well as to determine the crystallinity index.

\subsection{Electron microscopy}

To visualize the structures and dimensions of the cellulose nanofibers, a Jeol JEM 1200EXII transmission electron microscope $(600,000 \times)$ was used. The nanocellulosic suspensions were diluted in distilled water, which was then replaced by t-butyl alcohol (Iwamoto et al., 2008). The suspension diluted in alcohol was dripped on the surface of the mesh intended for observation under the microscope. The samples were left at room temperature for solvent evaporation and drying, forming nanocellulosic films.

Scanning electron microscopy (SEM) was used to visualize the dimensions of the tracheids before they were submitted to defibrillation. The papers were previously submitted to metallization and observed in an operating range of $0.5-30 \mathrm{k}$ to obtain the SEM images.

\subsection{Viscosity and crystallinity index}

Two samples from each treatment were submitted to viscosity and crystallinity index tests. The viscosity was determined in a cupriethylenediamine (CED) solution using a capillary viscometer according to the Tappi T 230 om-94 standard (Tappi, 1999a).

To determine the crystallinity structure of the cellulose in the papers and films, a Shimadzu XRD-7000 x-ray diffractometer was used along with the XRD-6100/7000 v. 5.0 software. The selected velocity for scanning was $1 \%$ min, varying between $3{ }^{\circ}$ and $45^{\circ}$, using $\mathrm{Cu}-\mathrm{Ka}$ radiation with wavelength of $0.15418 \mathrm{~nm}$ and voltage of $40 \mathrm{kV}$ with current of $20 \mathrm{~mA}$. The crystallinity index was determined by the method suggested by Segal et al. (1959). Using the Origin Pro 8.5 software, the data received smoothing treatment by Fourier Transform with $15 \%$ of the points cut to obtain the crystalline and amorphous intensity peaks.

\subsection{Physical and mechanical tests}

For each physical test, five samples were evaluated per treatment. The thickness of the films, expressed in micrometers $(\mu \mathrm{m})$, was determined following the Tappi T 411 om-97 standard (Tappi, 2004b). The density of the films, expressed in ${\mathrm{g} . \mathrm{cm}^{-3}}^{-3}$, was calculated as the ratio between the weight and the thickness of the paper. The films presented moisture of $9 \%$. Water absorbance was obtained through the Cobb method (expressed as g. $\mathrm{m}^{-2}$ ), according to which the water mass absorbed by one square meter of film or paper in a determined interval of time (in this case, 60 seconds) is measured. This method was adapted from the Tappi T 441 om-98 standard (Tappi, 2004c).

The tensile test was performed using a horizontal digital dynamometer with distance between clamps adjusted to $100 \mathrm{~mm}$ and a test velocity of $10 \mathrm{~mm}$. $\min ^{-1}$. The tensile strength was presented through tensile index, which corresponds to the ratio between the resistance and weight of the sample, expressed in N.m. $\mathrm{g}^{-1}$. The burst index, calculated through the ratio between burst resistance and weight of a sample, is expressed in $\mathrm{KPam}^{2} \cdot \mathrm{g}^{-1}$.

To evaluate the effect of the number of passes through the grinder, density properties, water absorbance, tensile strength, and the burst resistance of nanostructured films, the values were submitted to variance analysis, compared through the Tukey's test at 5\% probability. The Bartlett's test was previously performed to test homogeneity of variance. 


\section{RESULTS AND DISCUSSION}

\subsection{Electron microscopy}

Figures $2 \mathrm{a}$ and $2 \mathrm{~b}$, obtained through SEM, present characteristics of the Pinus' tracheids before they were submitted to the defibrillation process.

The images acquired through TEM related to the fibers from the cellulosic pulp after mechanical defibrillation with two and 40 passes are presented in Figures $3 \mathrm{a}$ and
$3 \mathrm{~b}$, respectively. It can be observed that the grinding process with two passes resulted in the fibrillation of the fiber's cell wall (tracheid) and in its reduction to nanofibers. Defibrillation promotes the exposure of surfaces previously situated in the interior of the fiber, the microfibrils, through the action of shear force. As a result, internal fibrillation occurs, which consists of the rupture of hydrogen bonds between the molecules of cellulose and hemicellulose inside the fiber, along with external fibrillation on the outside surface of the cellulose fibers.
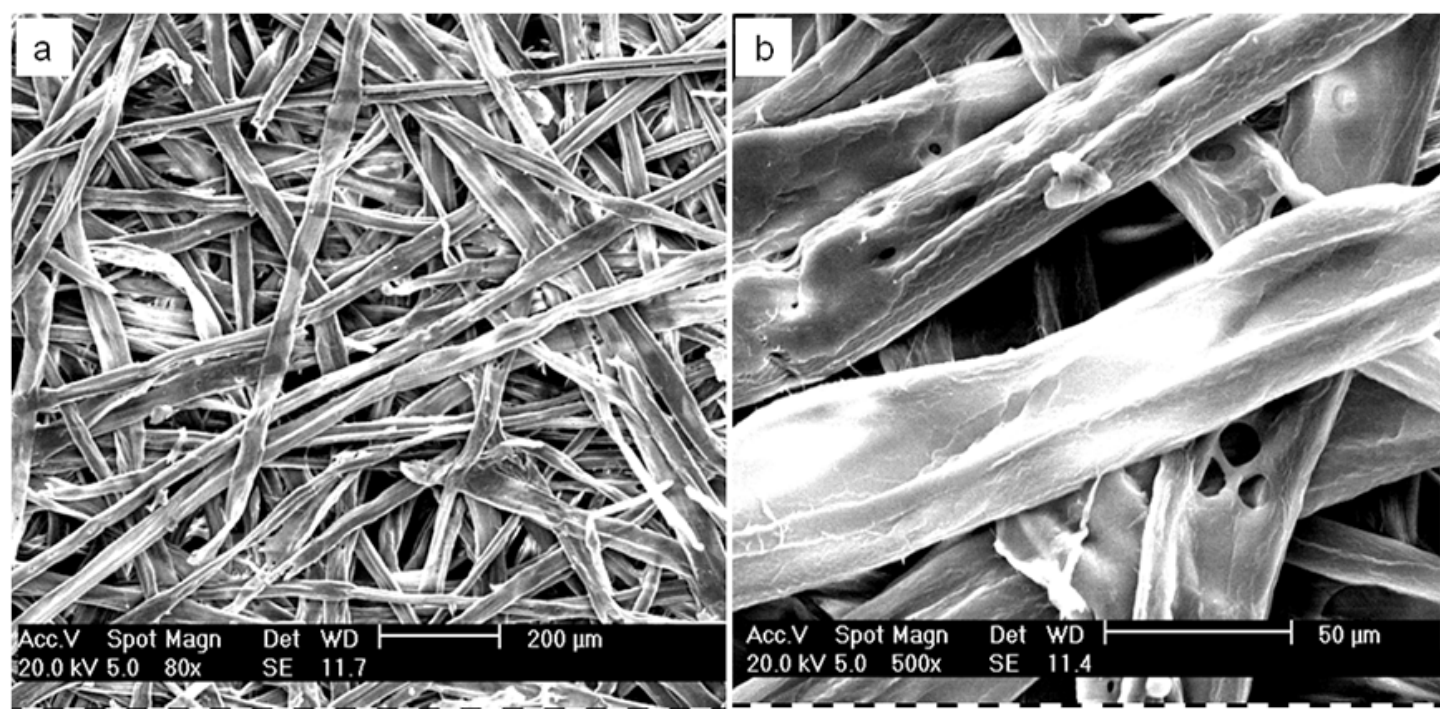

Figure 2. SEM images of kraft pulp tracheids from Pinus before the mechanical defibrillation process a) at $80 \times$ magnification; b) at $500 \times$ magnification.
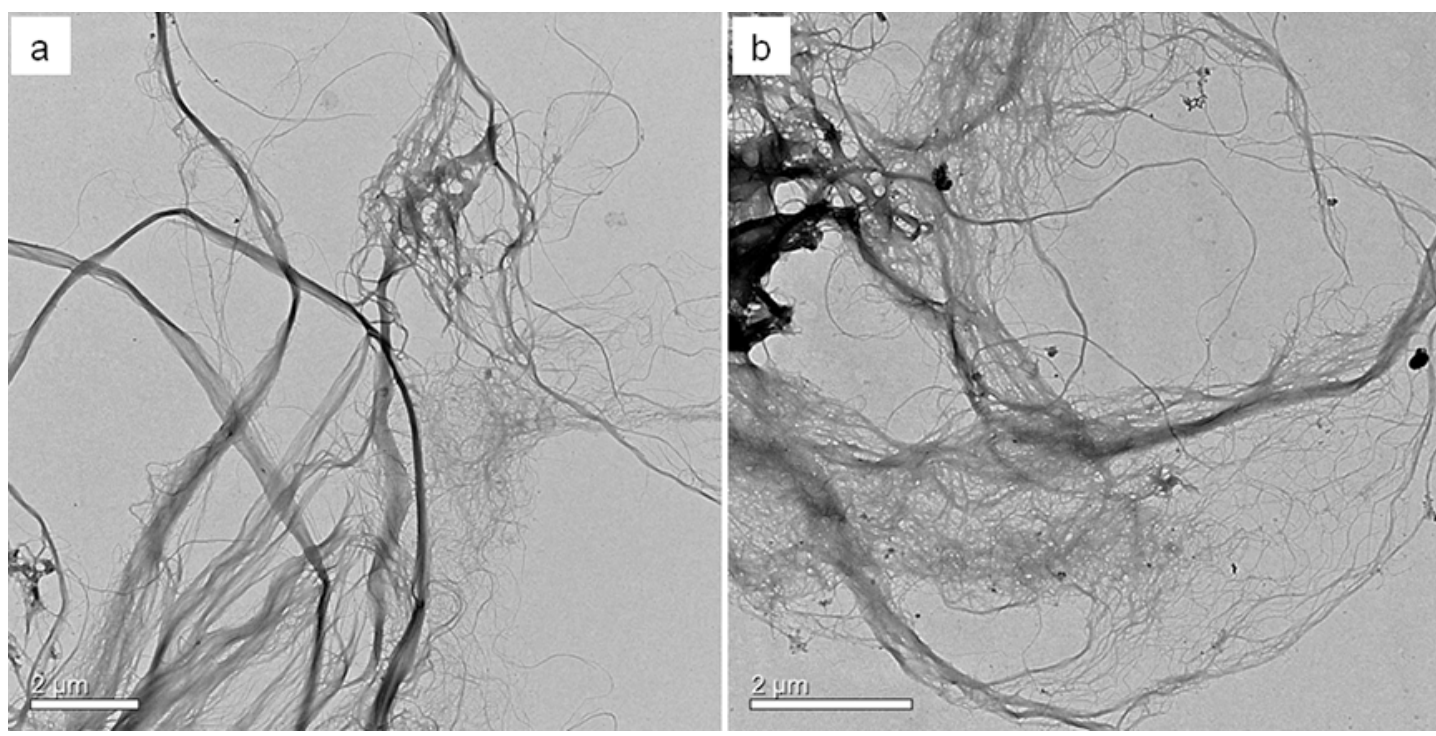

Figure 3. TEM images of cellulose nanofibers obtained with a) two passes; b) 40 passes. 
The Pinus wood's tracheids, which present an average diameter of around $40 \mu \mathrm{m}$, were completely defibrillated after the process, decreasing the fiber's width from dozens of micrometers to dozens of nanometers.

\subsection{Viscosity and crystallinity index}

To analyze the possible degradation experienced by the cellulose in the fiber, resulting from the mechanical process of defibrillation in the grinder, the viscosity and crystallinity of the papers and nanostructured films were measured after the different treatments. The results can be observed in Figure 4. Viscosity was used to indirectly evaluate the average degree of polymerization of the cellulose chains and detect cellulose degradation. A large decrease in viscosity can be observed in the T00 samples (20.13 mPa.s) in relation to the T02 treatment (13.72 mPa.s). The viscosity loss was significant, varying from $13.72 \mathrm{mPa} . \mathrm{s}$ for the nanocellulosic suspension obtained with two passes to $6.63 \mathrm{mPa}$.s for the nanofibers generated through 40 passes (Figure 4). The nanocellulosic suspension's viscosity decreased due to the increase in the number of passes through the grinder, suggesting higher carbohydrate depolymerization with the defibrillation process, as reported by other authors (Abe et al., 2009; Syverud et al., 2011).

The crystallinity index refers to the relative quantity of cellulose in the crystalline region (intercept), where the fiber presents higher resistance to tensile force, stretching, and solvation (Fengel \& Wegener, 1984). According to the adopted method, the crystalline cellulose percentage is calculated by the difference between the highest intensity peak (crystalline peak) and the lowest peak (amorphous peak). The highest crystallinity index obtained in this study was $81.8 \%$, for the treatment where the fibers were not submitted to mechanical processing (T00), and the lowest was $66.4 \%$, corresponding to the treatment with the highest number of passes (T40). Based on these results, the crystallinity and viscosity indices also decreased with an increase in the number of passes through the grinder, indicating that the crystalline structure was slightly degraded through the mechanical defibrillation, which causes the nanofibrillation of fibers, but at the same time promotes the degradation of cellulose, as seen by the decrease in the crystallinity index values and polymerization as the number of passes increases (Iwamoto et al., 2008; Kalia et al., 2014).

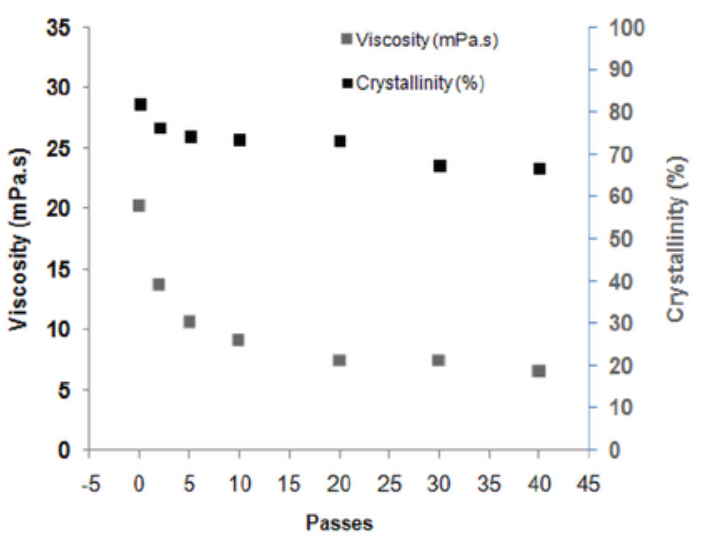

Figure 4. Crystallinity and viscosity of the papers and nanostructured films according to the number of passes through the grinder.

\subsection{Physical and mechanical tests}

Table 1 presents the physical properties of the papers and films (thickness, density, and Cobb $_{60}$ absorption) in relation to the number of passes through the grinder. The average thickness of the papers when fibers without mechanical treatment (T00) were used was $167 \mu \mathrm{m}$, while for the nanostructured films with different numbers of passes through the grinder the values varied from $56 \mu \mathrm{m}$ for the treatments with ten and 30 passes to $64 \mu \mathrm{m}$ for the treatment with two passes. The thickness of the films formed by nanofibers of cellulose presented the same tendency for all treatments, with threefold reduced thickness when compared to the papers with T00 treatment. The decrease in fibers' dimension after the defibrillation process in the grinder allowed a stronger connection and better arrangement of the nanofibers, allowing a more uniform and compact structure and decreasing the thickness of the films.

As a consequence of the reduced thickness, an increase in density can be observed in the same proportion for the nanostructured films. The density values varied from $0.33 \mathrm{~g} . \mathrm{cm}^{-3}$ for T00 to $1.16 \mathrm{~g} . \mathrm{cm}^{-3}$ for T30. The values found for the nanostructured films are close to those reported by other authors (Henriksson et al., 2008; Spence et al., 2010; Stelte \& Sanadi, 2009). The density has a strong and positive influence on the mechanical properties of paper and films. At the same time, it depends on the fibers' dimension: the smaller the fibers, the better the adaptation, thus producing denser films. 
The nanostructured films presented $\mathrm{Cobb}_{60}$ absorption values around three times smaller compared to those formed by fibers without mechanical treatment (T00) (Table 1). These papers presented the highest values, with average of $231.64 \mathrm{~g} . \mathrm{m}^{-2}$, and the group formed by treatments T02 and T05 presented the lowest values of water absorption, near $76.00 \mathrm{~g} . \mathrm{m}^{-2}$. According to Dufresne (2012), this behavior can be explained by the very compact structure and low porosity of nanostructured films, which decreases water penetration. The porosity, surface rugosity, moisture content, and hydrophobicity of the papers can influence the resistance to liquid penetration, as observed by Sjöström \& Alén (1999).

The enlargement of the fibers' specific surface with the defibrillation process favors a higher number of interfiber bonds due to the increased availability of $\mathrm{OH}$ groups (Carrasco et al., 1996; González et al., 2012). A denser nanostructured films structure indicates an increase in the Schopper-Riegler degree. The SchopperRiegler degree indicates the difficulty of water draining and expresses the resistance to drainage that has a layer of fibers. This increased retention can result in difficulties in draining water, causing operability problems during the formation of paper.

The mechanical property values of the nanostructured films can be observed in Table 2. The tensile strength (tensile index) showed an increase of approximately $300 \%$ with the presence of nanofibers in the films. The tensile index values varied from $26.24 \mathrm{Nm} . \mathrm{g}^{-1}$ for the T00 treatment to $114.60 \mathrm{Nm} . \mathrm{g}^{-1}$ for the T02 treatment.

The 02 treatment stood out with the highest resistance values. The burst index increased around ten times for treatments $\mathrm{T} 02, \mathrm{~T} 05$, and $\mathrm{T} 10$ in comparison with the treatment that did not go through the defibrillation process (T00). Treatments with two, five, and ten passes were statistically identical. Therefore, two passes through the grinder are enough to produce nanostructured films with higher tensile strength and burst resistance. From an economic standpoint, this is attractive because it requires less energy.

The significant increase in mechanical properties can be explained by the density increase, the denser network of hydrogen bonds created, and the bigger surface area produced by the defibrillation process (Spence et al., 2010).

Among the nanostructured films (Table 2), the treatment with 40 passes had the lowest mechanical resistance (Tensile Index $=66.56 \mathrm{Nm} \cdot \mathrm{g}^{-1}$ and Burst Index $\left.=3.33 \mathrm{KPam}^{2} \cdot \mathrm{g}^{-1}\right)$, coinciding with the lowest crystallinity and molecular weight of the cellulose. As can be seen in Figure 4, the viscosity of treatment T02 was $13.72 \mathrm{mPa}$.s, dropping to $6.63 \mathrm{mPa}$.s for treatment T40. The crystallinity index went from $76.1 \%$ (T02) to $66.4 \%$ (T40). With the sharp reduction of viscosity and the partial degradation of the cellulose chains, caused by increased intensity of the defibrillation, a decrease of the tensile and burst indices was also observed.

Despite the relationship between molecular weight and resistance properties of the cellulose fiber, these aspects should not be analyzed in isolation, since other factors also contribute to this, such as crystallinity, the fibers' anatomy, density and capacity of forming bonds, the films manufacturing process, and others. According to Gomide et al. (2005), higher viscosity is usually associated with better physical properties of

Table 1. Average values of thickness, density, and $\mathrm{Cobb}_{60}$ absorption properties of papers and nanostructured films.

\begin{tabular}{|c|c|c|c|c|c|c|}
\hline \multirow{2}{*}{ Treatments $^{a}$} & \multicolumn{2}{|c|}{ Thickness $(\mu \mathrm{m})$} & \multicolumn{2}{|c|}{ Density $\left(\right.$ g. $\left.\mathrm{cm}^{-3}\right)$} & \multicolumn{2}{|c|}{$\mathrm{Cobb}_{60}\left(\mathrm{~g} \cdot \mathrm{m}^{-2}\right)$} \\
\hline & Average & $\mathbf{S D}^{\mathbf{b}}$ & Average & SD & Average & SD \\
\hline T00 & 167 & 2.59 & $0.33(\mathrm{c})$ & 0.01 & $231.64(a)$ & 8.12 \\
\hline T02 & 64 & 1.40 & $1.03(b)$ & 0.09 & $75.66(d)$ & 3.54 \\
\hline T05 & 59 & 1.88 & $1.09(\mathrm{ab})$ & 0.03 & $75.86(d)$ & 1.67 \\
\hline T10 & 56 & 2.42 & $1.04(b)$ & 0.01 & $84.60(\mathrm{bcd})$ & 3.19 \\
\hline T20 & 57 & 1.31 & 1.13 (a) & 0.03 & $85.70(\mathrm{bc})$ & 2.91 \\
\hline T30 & 56 & 1.78 & 1.16 (a) & 0.05 & $76.99(\mathrm{~cd})$ & 2.85 \\
\hline T40 & 63 & 0.73 & 1.15 (a) & 0.02 & $87.64(b)$ & 6.08 \\
\hline
\end{tabular}

${ }^{\mathrm{a}} \mathrm{T}$ : treatments, with the numbers after $\mathrm{T}$ relating to the number of passes through the grinder; ${ }^{\mathrm{b}} \mathrm{SD}$ : standard deviation. Averages followed by the same lower-case letter are not different by the Tukey's test, with significance of $5 \%$. 
Table 2. Average values of tensile and burst indices of papers and nanostructured films.

\begin{tabular}{|c|c|c|c|c|}
\hline \multirow{2}{*}{ Treatments $^{a}$} & \multicolumn{2}{|c|}{ Tensile Index (Nm.g-1) } & \multicolumn{2}{|c|}{ Burst Index $\left(\mathrm{KPam}^{2} \cdot \mathrm{g}^{-1}\right)$} \\
\hline & Average & $\mathbf{S D}^{\mathrm{b}}$ & Average & SD \\
\hline T00 & $26.24(\mathrm{~d})$ & 0.82 & $0.85(\mathrm{~d})$ & 0.06 \\
\hline T02 & $114.60(a)$ & 8.56 & $8.38(\mathrm{a})$ & 0.53 \\
\hline T05 & $75.38(\mathrm{bc})$ & 4.07 & $8.71(\mathrm{a})$ & 0.71 \\
\hline T10 & $72.32(\mathrm{bc})$ & 3.82 & 8.45 (a) & 0.50 \\
\hline T20 & $80.23(b)$ & 10.50 & $4.76(\mathrm{~b})$ & 0.18 \\
\hline T30 & 80.06 (b) & 3.98 & $5.50(\mathrm{~b})$ & 0.35 \\
\hline $\mathrm{T} 40$ & $66.56(\mathrm{c})$ & 1.21 & $3.33(\mathrm{c})$ & 0.25 \\
\hline
\end{tabular}

${ }^{\mathrm{a}} \mathrm{T}$ : treatments, with the numbers after T relating to the number of passes through the grinder; ${ }^{\mathrm{b}} \mathrm{SD}$ : standard deviation. Averages followed by the same lower-case letter are not different by the Tukey's test, with significance of 5\%.

the pulp, but it does not necessarily guarantee papers with higher mechanical resistance.

Physical and mechanical properties depend on the degree of the bond between fibers, in which smaller and/ or fibrillated fibers provide a larger specific area and more contact points, increasing the number of bonds. More bonds promote higher density, tensile strength, and burst resistance. However, extensive defibrillation can negatively affect the mechanical properties of the nanostructured films by shortening the fibers, decreasing the polymerization degree of the cellulose chains, and causing a loss of crystallinity (Iwamoto et al., 2008; Sixta, 2006).

\section{CONCLUSIONS}

The results presented in this article allow the conclusion that the films constituted of nanofibers from mechanical defibrillation in a grinder display significant improvement in their physical and mechanical properties when compared to traditional papers (T00).

The average density value of the nanostructured films increased more than $200 \%$ in comparison with the papers formed by fibers that did not undergo mechanical treatment. Nanostructured films presented lower water absorption. Regarding mechanical properties, the presence of nanofibers in the films provided a $300 \%$ gain of tensile strength, and burst resistance was around ten times higher in the films when compared to the papers without mechanical processing.

The increase in the number of passes also causes a reduction of the crystallinity index and depolymerization of the cellulose. This reduction, from a certain number of passes, can entail a significant reduction of the mechanical properties of the nanostructured films.

\section{SUBMISSION STATUS}

Received: 30 Oct., 2015

Accepted: 28 Sept., 2018

\section{CORRESPONDENCE TO}

\section{Lívia Cássia Viana}

Universidade Federal do Paraná (UFPR), Engenharia e Tecnologia Florestal, Av. Pref. Lothário Meissner, 900, CEP 80050-490, Curitiba, PR, Brasil

e-mail: licvianna@gmail.com

\section{FINANCIAL SUPPORT}

The authors are thankful to Fundação Araucária and Coordenacão de Aperfeiçoamento de Pessoal de Nível Superior (Capes) for the financial support.

\section{REFERENCES}

Abe K, Iwamoto S, Yano H. Obtaining cellulose nanofibers with a uniform width of $15 \mathrm{~nm}$ from wood. Biomacromolecules 2007; 8(10): 3276-3278. 10.1021/ bm700624p

Abe K, Nakatsubo F, Yan H. High-strength nanocomposite based on fibrillated chemi-thermomechanical pulp. Composites Science and Technology 2009; 69(14): 24342437. 10.1016/j.compscitech.2009.06.015 
Abe K, Yano H. Comparison of the characteristics of cellulose microfibril aggregates isolated from fiber and parenchyma cells of Moso bamboo (Phyllostachys pubescens). Cellulose 2010 17(2): 271-277. 10.1007/s10570009-9382-1

Aulin C, Ström G. Multilayered alkyd resin/nanocellulose coatings for use in renewable packaging solutions with a high level of moisture resistance. Industrial \& Engineering Chemistry Research 2013; 52(7): 2582-2589. 10.1021/ ie301785a

Balea A, Blanco A, Monte MC, Merayo N, Negro C. Effect of bleached eucalyptus and pine cellulose nanofibers on the physico-mechanical properties of cartonboard. BioResources 2016; 11(4): 8123-8138. 10.15376/ biores.11.4.8123-8138

Balea A, Merayo N, Fuente N, Negro C, Delgado-Aguilar $\mathrm{M}$, Mutje $\mathrm{P}$ et al. Cellulose nanofibers from residues to improve linting and mechanical properties of recycled paper. Cellulose 2018; 25(2): 1339-1351. 10.1007/s10570017-1618-x

Berglund LA, Burgert I. Bioinspired wood nanotechnology for functional materials. Advanced Material 2018; 30(19): e1704285. 10.1002/adma.201704285

Besbes I, Vilar MR, Boufi S. Nanofibrillated cellulose from alfa, eucalyptus and pine fibres: preparation, characteristics and reinforcing potential. Carbohydrate Polymers 2011; 86(3): 1198-1206. 10.1016/j.carbpol.2011.06.015

Bharimalla AK, Deshmukh SP, Patil PG, Vigneshwaran $\mathrm{N}$. Energy efficient manufacturing of nanocellulose by chemo- and bio-mechanical processes: a review. World Journal of Nano Science and Engineering, 2015; 5(4): 204212. 10.4236/wjnse.2015.54021

Brodin FW, Gregersen ØW, Syverud K. Cellulose nanofibrils: challenges and possibilities as a paper additive or coating material: a review. Nordic Pulp \& Paper Research Journal 2014; 29(1): 156-166. 10.3183/npprj-2014-2901-p156-166

Campano C, Merayo N, Balea A, Tarrés Q, DelgadoAguilar M, Mutjé P et al. Mechanical and chemical dispersion of nanocellulose to improve their reinforcing effect on recycled paper. Cellulose 2018; 25(1): 269-280. 10.1007/s10570-017-1552-y

Carrasco F, Mutjé P, Pèlach MA. Refining of bleached cellulosic pulps: characterization by application of the colloidal titration technique. Wood Science and Technology 1996; 30(4): 227-236. 10.1007/BF00229345

Chinga-Carrasco G. Cellulose fibres, nanofibrils and microfibrils: the morphological sequence of MFC components from a plant physiology and fibre technology point of view. Nanoscale Research Letter 2011; 6: 417. $10.1186 / 1556-276 \mathrm{X}-6-417$

Dufresne A. Nanocellulose: from nature to high performance tailored materials. Berlin: De Gruyter; 2012.
Fall AB, Burman A, Wågberg L Cellulosic nanofibrils from eucalyptus, acacia and pine fibers. Nordic Pulp \& Paper Research Journal 2014; 29(1): 176-184. 10.3183/ npprj-2014-29-01-p176-184

Fengel D, Wegener G. Wood chemistry, ultrastructure, reactions. New York: De Gruyter; 1984.

Gomide JL, Colodette JL, Oliveira RC, Silva CM. Technological characterization of the new generation of Eucalyptus clones in Brazil for kraft pulp production. Revista Ârvore 2005; 29(1): 129-137. 10.1590/S010067622005000100014

González I, Alcalà M, Chinga-Carrasco GC, Vilaseca F, Boufi S, Mutjé P. From paper to nanopaper: evolution of mechanical and physical properties. Cellulose 2014; 21(4): 2599-2609. 10.1007/s10570-014-0341-0

González I, Boufi S, Pèlach MA, Alcalà M, Vilaseca F, Mutjé P. Nanofibrillated cellulose as paper additive in Eucalyptus pulps. BioResources 2012; 7(4): 5167-5180.

He M, Cho BU, Won JM. Effect of precipitated calcium carbonate: cellulose nanofibrils composite filler on paper properties. Carbohydrate Polymers 2016; 136: 820-825. 10.1016/j.carbpol.2015.09.069

Henriksson M, Berglund LA, Isaksson P, Lindström T, Nishino T. Cellulose nanopaper structures of high toughness. Biomacromolecules 2008; 9(6): 1579-1585. $10.1021 / \mathrm{bm} 800038 \mathrm{n}$

Herrera MA, Sirviö JA, Mathew AP, Oksman K. Environmental friendly and sustainable gas barrier on porous materials: nanocellulose coatings prepared using spin- and dip-coating. Materials \& Design 2016; 93: 19-25. 10.1016/j.matdes.2015.12.127

Ifuku S, Nogi M, Yoshioka M, Morimoto M, Yano $H$, Saimoto H. Fibrillation of dried chitin into 10-20 nm nanofibers by a simple grinding method under acidic condition. Carbohydrate Polymers 2010; 81(1): 134-139. 10.1016/j.carbpol.2010.02.006

International Organization for Standardization - ISO. ISO 5269-2: pulps: preparation of laboratory sheets for physical testing - part 2: Rapid-Köethen method. Geneva; 1980.

Ioelovich M, Larina E. Parameters of crystalline structure and their influence on the reactivity of $\mathrm{C} 1$. Cellulose Chemistry and Technology 1999; 33: 3-12.

Iwamoto S, Abe K, Yano H. The effect of hemicelluloses on wood pulp nanofibrillation and nanofiber network characteristics. Biomacromolecules 2008; 9(3): 1022-1026. 10.1021/bm701157n

Jonoobi M, Mathew AP, Oksman K. Producing low-cost cellulose nanofiber from sludge as new source of raw materials. Industrial Crops and Products 2012; 40(1): 232-238. 10.1016/j.indcrop.2012.03.018

Josset S, Orsolini P, Siqueira G, Tejado A, Tingaut P, Zimmermann T. Energy consumption of the nanofibrillation of bleached pulp, wheat straw and recycled 
newspaper through a grinding process. Nordic Pulp \& Paper Research Journal 2014; 29(1): 167-175. 10.3183/ npprj-2014-29-01-p167-175

Julkapli NM, Bagheri S. Nanocellulose as a green and sustainable emerging material in energy applications: a review. Polymers for Advanced Technologies 2017; 28(12): 1583-1594. 10.1002/pat.4074

Kalia S, Boufi S, Celli A, Kango S. Nanofibrillated cellulose: surface modification and potential applications. Colloid and Polymer Science 2014; 292(1): 5-31. 10.1007/s00396013-3112-9

Kargarzadeh H, Mariano M, Huang J, Lin N, Ahmad I, Dufresne A et al. Recent developments on nanocellulose reinforced polymer nanocomposites: a review. Polymer 2017; 132: 368-393. 10.1016/j.polymer.2017.09.043

Panthapulakkal S, Sain M. Preparation and characterization of cellulose nanofibril films from wood fibre and their thermoplastic polycarbonate composites. International Journal of Polymer Science 2012; 2012: 381342. $10.1155 / 2012 / 381342$

Segal L, Creely JJ, Martin AE Jr, Conrad CM. An empirical method for estimating the degree of crystallinity of native cellulose using the X-ray diffractometer. Textile Research Journal 1959; 29(10): 786-794. $10.1177 / 004051755902901003$

Shimizu M, Saito T, Isogai A. Water-resistant and high oxygen-barrier nanocellulose films with interfibrillar cross-linkages formed through multivalent metal ions. Journal of Membrane Science 2016; 500: 1-7. 10.1016/j. memsci.2015.11.002

Sixta H, editor. Handbook of pulp. Weinheim: WileyVCH; 2006.

Sjöström E. Wood chemistry: fundamentals and applications. 2nd ed. London: Academic Press; 1993.

Sjöström E, Alén R, editors. Analytical methods in wood chemistry, pulping, and papermaking. Berlin: Springer; 1999.

Spence KL, Venditti RA, Rojas OJ, Habibi Y, Pawlak JJ. The effect of chemical composition on microfibrillar cellulose films from wood pulps: water interactions and physical properties for packaging applications. Cellulose 2010; 17(4): 835-848. 10.1007/s10570-010-9424-8

Stelte W, Sanadi AR. Preparation and characterization of cellulose nanofibers from two commercial hardwood and softwood pulps. Industrial \& Engineering Chemistry Research 2009; 48(24): 11211-11219. 10.1021/ie9011672

Suopajärvi T, Sirviö JA, Liimatainen H. Nanofibrillation of deep eutectic solvent-treated paper and board cellulose pulps. Carbohydrate Polymers 2017; 169: 167-175. 10.1016/j.carbpol.2017.04.009

Syverud K, Chinga-Carrasco G, Toledo J, Toledo PG. A comparative study of Eucalyptus and Pinus radiata pulp fibres as raw materials for production of cellulose nanofibrils. Carbohydrate Polymers 2011; 84(3): 10331038. 10.1016/j.carbpol.2010.12.066

Technical Association of the Pulp and Paper Industry Tappi. T $230 \mathrm{om}-94$ : viscosity of pulp: capillary viscometer method. Atlanta: Tappi Press, 1999a.

Technical Association of the Pulp and Paper Industry - Tappi. T 236 om-85: kappa number of pulp. Atlanta: Tappi Press, 1999b.

Technical Association of the Pulp and Paper Industry Tappi. T 205 sp-02: forming handsheets for physical tests of pulp. Norcross: Tappi Press, 2004a.

Technical Association of the Pulp and Paper Industry Tappi. T 411 om-97: thickness of paper, paperboard, and combined board. Norcross: Tappi Press, 2004b.

Technical Association of the Pulp and Paper Industry - Tappi. T 441 om-98: water absorptiveness of sized (nonbibulous) paper, paperboard, and corrugated fiberboard (Cobb test). Norcross: Tappi Press, 2004c.

Toivonen MS, Kurki-Suonio S, Schacher FH, Hietala S, Rojas OJ, Ikkala O. Water-resistant, transparent hybrid nanopaper by physical cross-linking with chitosan. Biomacromolecules 2015; 16(3): 1062-1071. 10.1021/ acs.biomac.5b00145

Turbak AF, Snyder FW, Sandberg KR. Microfibrillated cellulose, a new cellulose product: properties, uses, and commercial potential. Journal of Applied Polymer Science: Applied Polymer Symposium 1983; 37: 815-827.

Vandermoere F, Blanchemanche S, Bieberstein A, Marette $\mathrm{S}$, Roosen J. The public understanding of nanotechnology in the food domain: the hidden role of views on science, technology, and nature. Public Understanding of Science 2011; 20(2): 195-206. 10.1177/0963662509350139

Vartiainen J, Pöhler T, Sirola K, Pylkkänen L, Alenius H, Hokkinen $\mathrm{J}$ et al. Health and environmental safety aspects of friction grinding and spray drying of microfibrillated cellulose. Cellulose 2011; 18(3): 775-786. 10.1007/s10570011-9501-7

Wang H, Li D, Zhang R. Preparation of ultralong cellulose nanofibers and optically transparent nanopapers derived from waste corrugated paper pulp. BioResources 2013; 8(1): 1374-1384.

Wang W, Mozuch MD, Sabo RC, Kersten P, Zhu JY, Jin Y. Production of cellulose nanofibrils from bleached eucalyptus fibers by hyperthermostable endoglucanase treatment and subsequent microfluidization. Cellulose 2015; 22(1): 351-361. 10.1007/s10570-014-0465-2

Wise LE, Murphy M, D’Addieco AA. A chlorite holocellulose, its fractionation and bearing on summative wood analysis and studies on the hemicelluloses. Paper Trade Journal 1946; 122(2): 35-43. 